\title{
Skin Reactions in Patients With Multiple Sclerosis Receiving Cladribine Treatment
}

Leoni Rolfes, MD, Steffen Pfeuffer, MD, Jana Hackert, MD, Marc Pawlitzki, MD, Tobias Ruck, MD, Wiebke Sondermann, MD, Melanie Korsen, MD, Heinz Wiendl, MD, Sven G. Meuth, MD, PhD, Christoph Kleinschnitz, MD, and Refik Pul, MD

Neurol Neuroimmunol Neuroinflamm 2021;8:e990. doi:10.1212/NXI.0000000000000990

\section{Abstract}

\section{Objective}

To report 77 patients with multiple sclerosis (MS) who developed skin-related adverse events (AEs) following treatment with cladribine.

\section{Methods}

We evaluated our prospective bicentric cladribine cohort. Cladribine-treated patients with a skin $\mathrm{AE}$ were identified.

\section{Results}

Two hundred thirty-nine cladribine-treated patients with MS were evaluated. Seventy-seven patients (32\%) showed at least 1 skin $\mathrm{AE}$ at median 1 month after cladribine initiation (range: 1-12). Within first 3 months following last cladribine exposition, hair thinning $(n=28,12 \%)$, skin rash $(n=20 ; 8 \%)$, mucositis $(n=13,5 \%)$, and pruritus $(n=6,3 \%)$ were observed. Furthermore, 35 patients (15\%) developed herpes virus infections (time since last cladribine exposition: median 83 [range: 10-305]). In 15 patients, herpes zoster infection was severe (CTCAE grade $\geq 3$ ) and required hospitalization. Delayed skin AEs ( $\geq 3$ months after a cladribine treatment cycle) involved 1 case of leukocytoclastic vasculitis and 2 cases of alopecia areata. Finally, 2 patients presented with in total 3 isolated precancerous lesions ( 1 leukoplakia simplex and 2 actinic keratosis) and 1 patient developed a squamous cell carcinoma.

\section{Conclusion}

Skin AEs are common in patients with MS treated with cladribine. Until risk management plans have been adjusted to include these phenomena, clinicians should perform a thorough clinical follow-up and in suspicious cases seek early interdisciplinary support. In light of the observed delayed skin reactions, we further emphasize the necessity of careful clinical surveillance of cladribine-treated patients for yet undescribed secondary autoimmune events.

\section{Classification of Evidence}

This study provides Class IV evidence that skin-related AEs are frequent in patients with MS following cladribine in a real-world setting.
Correspondence

Dr. Rolfes,

leoni.rolfes@ukmuenster.de

\section{MORE ONLINE}

$\rightarrow$ Class of Evidence

Criteria for rating

therapeutic and diagnostic

studies

NPub.org/coe 


\section{Glossary}

$\mathbf{A E}=$ adverse event; $\mathbf{D M T}$ = disease-modifying therapy; $\mathbf{M S}=$ multiple sclerosis; RRMS = relapsing-remitting MS.

Skin-related adverse events (AEs) have been described in several disease-modifying therapies (DMTs) approved for treatment of relapsing-remitting multiple sclerosis (RRMS). ${ }^{1}$ However, little is known about the incidence and clinical presentation of such AEs in patients treated with cladribine. Dermatomal herpes infections and rare cases of skin rash are the only described (transient) skin-related AEs of cladribine so far. ${ }^{2,3}$ Moreover, there has long been uncertainty whether cladribine treatment increases the risk of malignancy.

Here, we present our prospective, bicentric cohort of 239 cladribine patients, 77 (32\%) of whom developed at least 1 skin-related $\mathrm{AE}$ of varying severity.

\section{Methods}

We evaluated our prospective, bicentric cohort of patients with RRMS who received oral cladribine according to the latest summary of product characteristics. Following treatment induction, patients were evaluated at least every third month. Patients with skin-related AEs were identified, and baseline characteristics (e.g., age, sex, concomitant diagnosis and therapies, smoker status, and family history) as well as data regarding the $\mathrm{AE}$ (date of $\mathrm{AE}$, concomitant clinical events, supportive medications, and lymphocyte count) were evaluated.

\section{Standard Protocol Approvals, Registrations, and Patient Consents}

Ethical approval was obtained from local authorities (2020459-f-S), and patients gave informed consent.

\section{Data Availability}

Data will be shared with qualified investigators on request; please contact leoni.rolfes@ukmuenster.de.

\section{Results}

Two hundred thirty-nine cladribine-treated patients with RRMS were longitudinally evaluated (table 1 ). Seventy-seven patients (32\%) developed 1 or more (median number 1.5 [range: 1-6]) skin AEs. Generally, acute skin reactions $(<3$ months following a cladribine treatment course) represented the most common phenomenon, with 54 patients (22.6\%) reporting at least 1 event (table 2). In detail, 28 patients (11.7\%) described diffuse hair thinning, and 20 patients (8.4\%) experienced a skin rash, including diffuse erythema $(n=13$, $5.4 \%)$, nummular eczema $(\mathrm{n}=2,0.8 \%)$, and papulopustular acneiform eruption (acneiform rash, $\mathrm{n}=5,2.1 \%$, figure, $\mathrm{A}-\mathrm{C}$ ). Of interest, 6 patients who developed a rash at cladribine initiation experienced it at reexposure during the second course.
In 2 cases $(0.8 \%)$, skin rash was accompanied by pruritus, whereas in 4 patients (1.7\%), pruritus represented as an isolated symptom (figure D). Furthermore, 13 patients (5.4\%) demonstrated with transient mucositis, including 2 cases of dental abscess, even leading to teeth loss in 1 patient and surgical abscess splitting in the other. Most cases of acute symptoms resolved without specific treatment (except 7 cases of symptomatic treatment with local steroids and/or antihistamines due to skin rash and pruritus). However, 6 cases (2.5\%) of hair thinning and 3 (1.3\%) of acneiform rash persisted during the follow-up (median 21 [range: 6-26] months).

Moreover, 35 patients (14.6\%) developed a herpetic skin infection (herpes zoster: $\mathrm{n}=16,6.7 \%$ [figure $\mathrm{E}$ ]; herpes simplex: $n=19,7.9 \%$; figure $F$ and table 2 ). Of note, $88 \%$ of herpes zoster infections $(\mathrm{n}=15$, including 1 zoster ophthalmicus, 2 disseminated infections (figure $\mathrm{E}$ ), and 1 trigeminal nerve affection) were rated as severe (CTCAE grade $\geq 3$ ) and needed hospitalization. Because an integrated analysis of safety data from the cladribine development program suggested a correlation between lymphopenia and the incidence of herpes zoster, ${ }^{2}$ we evaluated lymphocyte counts at infection onset. Indeed, $88 \%(\mathrm{n}=15)$ of herpes zoster and $74 \%$ of herpes simplex infections manifested during lymphopenia (median lymphocyte count herpes zoster: 570 [range: $220-1,120$ ] cells $/ \mu \mathrm{L}$; herpes simplex: 860 [range: $420-1,150]$ cells $/ \mu \mathrm{L})$.

We further observed 7 cases $(2.9 \%)$ of delayed skin reactions (onset $\geq 3$ months following cladribine treatment, table 2). Those included 3 cases of acneiform rash (median 144 [range: 130-174] days following cladribine therapy), 1 case of delayed hair thinning (day 206 of cladribine therapy), and —of particular interest -1 case of leukocytoclastic vasculitis and 2 cases of alopecia areata (22/20/13 months after cladribine initiation), probably representing secondary autoimmune complications of cladribine treatment in MS. In detail, a 42-year-old woman received the diagnosis of leukocytoclastic vasculitis, based on the clinical presentation (palpable purpura on both lower legs, figure $\mathrm{G}$ ), findings in the direct immunofluorescence and good response to local as well as systemic steroid treatment. She showed no symptoms of systemic vasculitis, and further laboratory tests were inconspicuous. During 3 months of follow-up, purpuras improved in size and palpability while the patient continues to take steroids in an oral tapering regime.

Moreover, 2 female patients (27 and 38 years old) reported smooth, circular areas of complete hair loss. In both cases, consultation of a dermatologist resulted in the diagnosis of alopecia areata based on the classical clinical presentation (figure $\mathrm{H}$ ). Laboratory tests including thyroid hormones and 
Table 1 Baseline Characteristics of the Cladribine Cohort (Total $\mathrm{N}=239$ Patients)

\begin{tabular}{ll}
\hline Cladribine cohort & \\
\hline Patients, no. (\%) & 239 \\
\hline Age, y, median (IQR) & $40(33-46)$ \\
\hline Male patients, no. (\%) & $91(38)$ \\
\hline Time since RMS onset, y, median (IQR) & $4.2(0.9-9.0)$ \\
\hline EDSS baseline, median (IQR) & $2.0(1.5-3.0)$ \\
\hline ARR; baseline, median (IQR) & $1(0-2)$ \\
\hline Total number of previous DMTs, median (IQR) & $1(0-2)$ \\
\hline Last previous DMT, no. (\%) & $72(30)$ \\
\hline Treatment naive & $117(49)$ \\
\hline Basic treatment & $50(21)$ \\
\hline Escalation treatment & $72(30)$ \\
\hline Reason for switch to CLD, no. (\%) & $118(50)$ \\
\hline Treatment initiation & $48(20)$ \\
\hline Disease progression & $49.0(17-88)$ \\
\hline Adverse events & $23.7(16.2-29.5)$ \\
\hline Washout duration, d, median (IQR) & \\
\hline Follow-up duration, mo, median (IQR) & \\
\hline
\end{tabular}

Abbreviation: IQR, interquartile range.

Disease duration was defined as the time between diagnosis and last followup date. Basic includes the following DMT: interferon-beta, glatiramer acetate, teriflunomide, and dimethyl fumarate. Escalation includes fingolimod, natalizumab, and daclizumab. The Expanded Disability Status Scale and the annualized relapse rate refer to the time before cladribine initiation.

thyroid antibodies revealed no alternative underlying course. Alopecia persisted during follow-up periods of 6 and 19 months, respectively.

Finally, single cases of skin carcinomas have been described in cladribine-treated patients with MS. ${ }^{5-7}$ Here, we observed in total 3 precancerous lesions (leukoplakia simplex and 2 cases of actinic keratosis) and 1 case of squamous cell carcinoma in 2 cladribine-treated patients with MS. In detail, a 41-year-old woman presented with oral leukoplakia that was first noted 67 days following cladribine exposition (figure I). Biopsy confirmed the diagnosis of leukoplakia simplex. No specific therapy was initiated and restitution occurred during a 1-year follow-up. However, at day 153 of cladribine treatment, the patient developed actinic keratosis (figure J). The lesion was excised, followed by topical therapy with diclofenac sodium.

Moreover, a 69-year-old female patient with MS required escalation treatment due to persisting relapse activity. Ultraviolet damaged skin and a medical history of actinic keratosis were evident, however stable for years. Of note, 68 days after the first cladribine treatment cycle, she presented with several firm and indolent lesions with central hyperkeratosis (figure
$\mathrm{K})$. Biopsies revealed the diagnosis of 4 squamous cell carcinomas and 4 actinic keratoses. The lesions were excised, and no further specific treatment was initiated. She is regularly screened (every 6 months) for reemerging disease activity.

\section{Discussion}

Skin-related AEs, especially skin rash, have been described before in cladribine treatment for oncologic purpose ${ }^{8}$; however, are lessconsidered AEs of cladribine treatment in $\mathrm{MS}^{3}$ and are not mentioned in the risk management plans of MS so far.

In this prospective study, we demonstrate that skin-related AEs are frequent, with 77 of 239 cladribine-treated patients (32\%) experiencing at least 1 treatment-emerged $\mathrm{AE}$. Acute to subacute AEs thereby represent the most common phenomenon (22.6\%), with hair loss being the dominant manifestation. Nonhematologic toxicity might be an underlying mechanism (especially in regard to alopecia, mucositis, and acneiform rash), probably also being an explanation for other side effects reported by controlled clinical trials (e.g., nausea, diarrhea, and fatigue)., ${ }^{2,49}$ Moreover, skin rash or pruritus might further represent immunemediated skin phenomena. Previously, it has been postulated that cladribine-induced immune dysregulation might not be the direct cause of skin rash in hemato-oncologic patients, rather than predisposes patients to be hypersensitive to other drugs. ${ }^{8} \mathrm{How}-$ ever, none of our patients experienced skin rash associated with concomitant therapy. Generally, most cases of acute reactions resolved without specific treatment while cladribine was continued. Only in 1 patient, the $\mathrm{AE}$ (squamous cell carcinoma) led to treatment discontinuation.

Moreover, our cohort indicates a high number of skin infections (herpes zoster: $\mathrm{n}=16,6.7 \%$; herpes simplex: $\mathrm{n}=19$, $7.9 \%)$, contrasting the herpes zoster/simplex infection rate of $2.0 \% / 3.0 \%$ in the cladribine $3.5 \mathrm{mg} / \mathrm{kg}$ group of the CLARITY trial and its extension. ${ }^{4,9}$ Importantly, there was a high percentage of severe disease courses ( $88 \%$ of herpes zoster infections) that required inpatient therapy.

Of interest, 2 patients showed hair loss due to alopecia areata, and 1 presented with a leukocytoclastic vasculitis. Because there are spontaneous manifestations described, we cannot unequally demonstrate a causal relationship between those phenomena and cladribine in these reported cases. However, the autoimmune pathophysiology against the background of long-lasting changes of cladribine in the immune system, the identification of other cases of alopecia areata associated with DMTs, ${ }^{1}$ and the typical time course of secondary autoimmunity beginning from 13 months after initiation of immune reconstitution ${ }^{1}$ might argue in favor of a lymphopeniaassociated secondary autoimmune disease. Indeed, both patients (1 with alopecia areata and 1 with leukocytoclastic vasculitis) from whom we had blood counts at the time of autoimmunity showed lymphopenia (850 and 910 cells $/ \mu \mathrm{L}$ ). Of interest, both patients developed autoimmunity from a 
Table 2 Manifestation of Cladribine-Related Skin Reactions (Total N = 239 Patients)

\begin{tabular}{|c|c|c|}
\hline Skin reaction & Patients, no. (\%) & Time since last treatment cycle, $d$, median (range) \\
\hline Patients with at least 1 skin reaction & $77(32.2)$ & $36(2-272)$ \\
\hline Acute skin reactions & $54(22.6)$ & $18(2-75)$ \\
\hline Hair thinning & $28(11.7)$ & $16(3-65)$ \\
\hline Skin rash & & $28(2-65)$ \\
\hline Diffuse erythema & $13(5.4)$ & \\
\hline Acneiform rash & $5(2.1)$ & \\
\hline Nummular eczema & $2(0.8)$ & \\
\hline Mucositis & $13(5.4)$ & $34.5(2-75)$ \\
\hline Pruritus & $6(2.5)$ & $11(2-54)$ \\
\hline Skin infections & $35(14.6)$ & $83(10-305)$ \\
\hline Herpes zoster & $16(6.7)$ & $90(10-237)$ \\
\hline Herpes simplex & $19(7.9)$ & $83(16-305)$ \\
\hline Delayed skin reactions & $7(2.9)$ & $159(7-272)$ \\
\hline Acneiform rash & $3(1.3)$ & $144(130-174)$ \\
\hline Hair thinning & $1(0.4)$ & 206 \\
\hline Alopecia areata & $2(0.8)$ & $122(7-237)$ \\
\hline Leukocytoclastic vasculitis & $1(0.4)$ & 272 \\
\hline Precancerous/cancerous lesions & $2(0.8)$ & $67(35-153)$ \\
\hline Leukoplakia simplex & $1(0.4)$ & 67 \\
\hline Actinic keratosis & $2(0.8)$ & $106(59-153)$ \\
\hline Squamous cell carcinoma & $1(0.4)$ & 120 \\
\hline
\end{tabular}

Skin reactions of the 76 identified cases are classified into acute events ( $\leq 3$ months after a cladribine treatment cycle), skin infections, delayed skin reactions (onset $>3$ months following cladribine treatment), and precancerous lesions. Number of patients with a respective event is outlined; percentage is given in relation to the entire cohort of 239 cladribine-treated patients. Duration since last treatment cycle refers to the time period between the last cladribine intake (irrespective of whether it is the first or second cycle) and the first manifestation of the respective skin reaction.

moderate state of immunosuppression with a $\mathrm{CD} 19^{+} \mathrm{B}$ cell of 51 cells $/ \mu \mathrm{L}$ and 100 cells $/ \mu \mathrm{L}$, respectively. T-cell counts were normal $\left(724\right.$ and $670 \mathrm{CD}^{+}$cells/ $\mu \mathrm{L} ; 411$ and $334 \mathrm{~T}$ helper cells $/ \mu \mathrm{L} ; 253$ and 150 cytotoxic $\mathrm{T}$ cells $/ \mu \mathrm{L})$. Of note, a significant increase in the relative proportion of $\mathrm{T}$ cells expressing the activation marker HLA-DR was observed in the patients with alopecia areata (increase from $4.8 \%$ to $16.8 \%$ at the onset of autoimmunity). Because the last cladribine treatment course particularly narrowed the difference between activated $\left(\mathrm{CD}^{+-}\right.$ HLA-DR ${ }^{+}$) and nonactivated (CD3 ${ }^{+} \mathrm{HLA}^{\left.-\mathrm{DR}^{-}\right)} \mathrm{T}$ cells, it can be speculated that this may have caused an imbalance to the disadvantage of regulatory $\mathrm{T}$ cells. Indeed, there are several lines of evidence suggesting that alopecia areata is a primary $\mathrm{T}$ cellmediated autoimmune condition. In contrast, the pathomechanism of leukocytoclastic vasculitis is still unclear. T helper cells appear to be involved in disease induction, ${ }^{10}$ but in this particular case showed no dynamics during disease onset.

Moreover, it is currently unknown whether the reported cases showed expression of risk alleles for the respective autoimmune phenomenon; however, this should be investigated in future cases to further assess individual risk profiles. ${ }^{11}$

In addition, and in view of cladribine's mechanism of action, the risk of malignancy was thoroughly evaluated in clinical studies. Although CLARITY and its extension outlined a higher incidence of overall malignancies in the verum group, ${ }^{9}$ independent reviews showed a similar rate of malignancy with cladribine compared with other DMTs or in comparison to healthy population. ${ }^{2}$ Here, we report 3 precancerous skin lesions and 1 case of malignant squamous cell carcinoma in 2 cladribinetreated individuals $(0.8 \%)$, not exceeding the expected overall rate of neoplasms as outlined by CLARITY. ${ }^{9}$ Of note, benign (seborrheic keratosis, skin papilloma, and melanocytic nevus) and malignant (squamous cell carcinoma, basal cell carcinoma, and malignant melanoma) isolated skin carcinomas have been previously described in the context of cladribine treatment. ${ }^{5-7}$

In conclusion, we report 77 cases of skin AEs, associated with cladribine treatment. Taking into account the high frequency, 

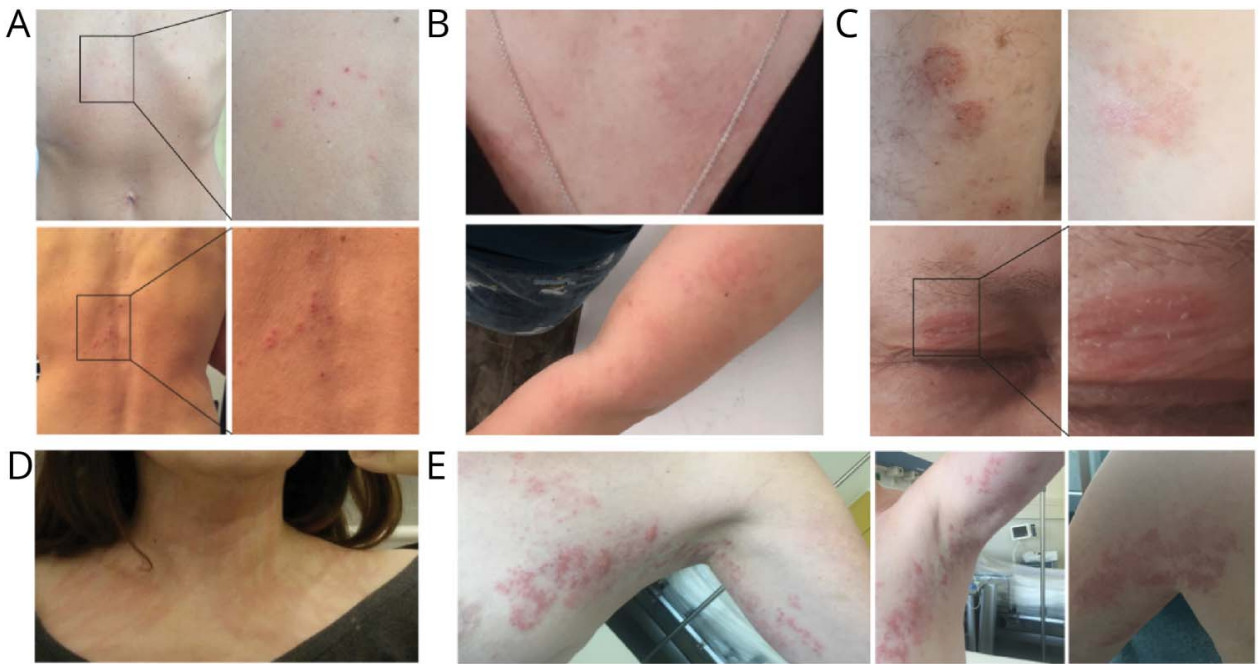

$\mathrm{F}$
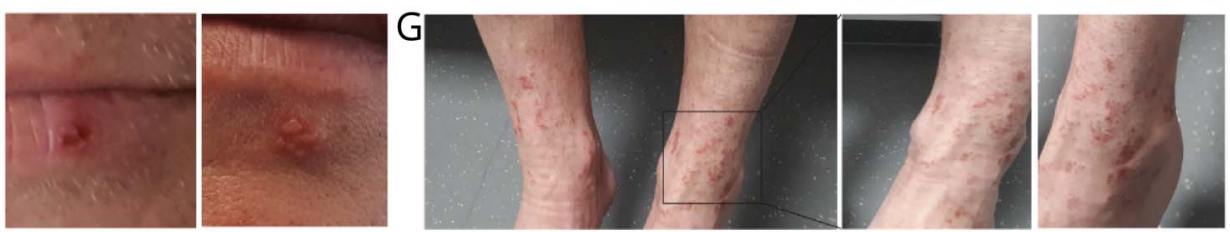

$\mathrm{H}$
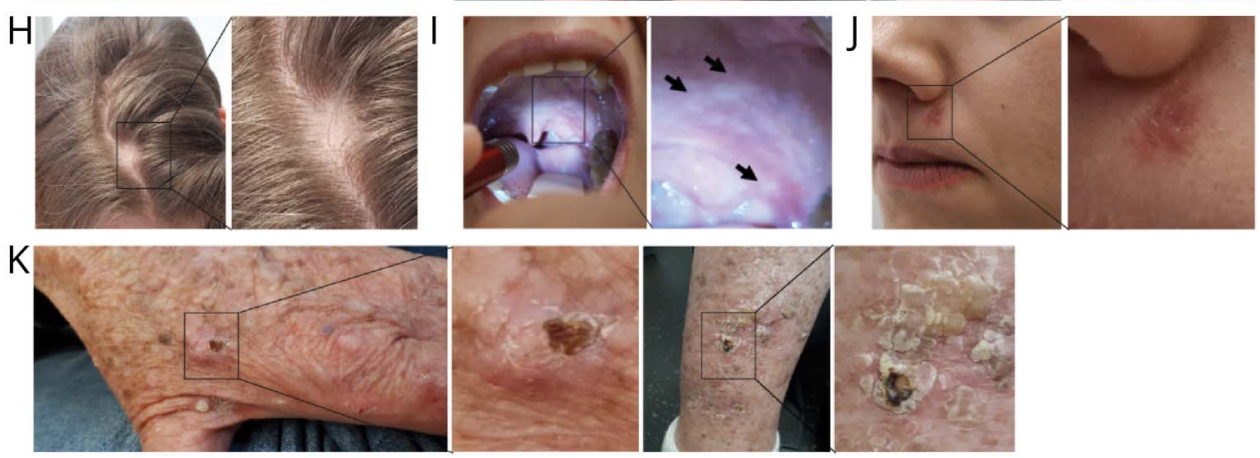

(A) Acneiform eruption consisted of follicle-based papules without comedones and lesions typically occurred on the face, scalp, chest, and back, sparing the extremities. (B) Representative images of 1 patient, experiencing diffuse skin rash. (C) Nummular eczema typically occurred as itchy coin-sized round- to ovoid-shaped red plaques in 2 cladribine-treated individuals. (D) An example of a female patient with severe and unbearable itching. (E) Disseminated herpes zoster infection of left Th1 to Th4 dermatomes. (F) Representative images of herpes simplex infection following cladribine treatment. (G) Typical presentation of a leukocytoclastic vasculitis with palpable purpura, accompanied by pain and burning at both legs, in a 42-year-old female cladribine-treated patient with MS. (H) A case of alopecia areata with typical hair loss in one round spot on the scalp. (I) Oral leukoplakia simplex in a 41-year-old cladribinetreated patient. Typical white changes of the buccal mucosa are depicted (black arrows). () Actinic keratosis manifested as a rough, dry patch of skin, of approximately $1.5 \mathrm{~cm}$ in diameter in a 41year-old cladribine-treated patient. (K) A 69-year-old female patient with MS developed squamous cell carcinomas on sun-exposed skin (hand and legs), appearing as hyperkeratotic plaque with central ulceration and/or crusted surface.

as well as the in part autoimmune origin, it should be carefully evaluated whether patients prone to skin irritation should receive treatment with cladribine. Moreover, we emphasize the necessity of careful clinical surveillance of cladribine-treated patients to warrant early diagnosis and prompt treatment. In this context, we consider that a complete clinical examination of the skin at regular intervals should be mandatory for all patients. In particular, our cases of alopecia areata and leukocytoclastic vasculitis further demonstrate that clinicians must to be aware of and screen yet undescribed (secondary) autoimmune phenomena. Large register studies are necessary to establish the true incidence and the clinical impact of skin AEs in cladribine-treated patients with MS in the future.

\section{Study Funding}

No targeted funding reported.

\section{Disclosure}

L. Rolfes received travel reimbursements from Merck Serono and Sanofi Genzyme. S. Pfeuffer received travel reimbursements from Sanofi-Genzyme and Merck Serono, honoraria for lecturing from Sanofi Genzyme, Biogen, and Mylan Healthcare and research support from Merck Serono, Diamed, and the German Multiple Sclerosis Society. J. Hackert reports no disclosures relevant to the manuscript. M. Pawlitzki received travel/ accommodation/meeting expenses from Novartis. T. Ruck reports grants from the German Ministry of Education, Science, Research and Technology, grants and personal fees from SanofiGenzyme and Alexion; personal fees from Biogen, Roche and Teva; personal fees and nonfinancial support from Merck Serono, outside the submitted work. W. Sondermann and M. Korsen report no disclosures relevant to the manuscript. $\mathrm{H}$. Wiendl received grants from the German Ministry for Education and Research (BMBF), Deutsche Forschungsgesellschaft (DFG), Else Kröner Fresenius Foundation, Fresenius Foundation, the European Union, Hertie Foundation, NRW Ministry of Education and Research, Interdisciplinary Center for Clinical Studies (IZKF) Muenster and RE Childrens Foundation, Biogen, GlaxoSmithKline GmbH, Roche Pharma AG, and SanofiGenzyme; consulting fees from Abbvie, Actelion, Biogen, IGES, 
Johnson \& Johnson, Novartis, Roche, and Sanofi-Aventis; support for travel to meetings for other purposes from Abbvie, Actelion, Biogen, IGES, Johnson \& Johnson, Novartis, Roche, and Sanofi-Aventis; fees for participation in review activities such as data monitoring boards from PSI CRO Deutschland GmbH, Swiss Multiple Sclerosis Society; payment for lectures from Alexion, Biogen, Cognomed, F. Hoffmann-La Roche Ltd., Gemeinnützige Hertie-Stiftung, Merck Serono, Novartis, Roche Pharma AG, Genzyme, TEVA, and WebMD Global; honorarium for expert testimony from Alexion, Biogen, Merck Serono, Novartis, and Genzyme outside the submitted work. He has filed patents No SEP-103.323-1/08, EP2769223, WO2013057092 (A1), and 15001186.41402; S.G. Meuth received honoraria for lecturing and travel expenses for attending meetings from Almirall, Amicus Therapeutics Germany, Bayer Health Care, Biogen, Celgene, Diamed, Genzyme, MedDay Pharmaceuticals, Merck Serono, Novartis, Novo Nordisk, ONO Pharma, Roche, Sanofi-Aventis, Chugai Pharma, QuintilesIMS, and Teva. His research is funded by the German Ministry for Education and Research (BMBF), Deutsche Forschungsgemeinschaft (DFG), Else Kröner Fresenius Foundation, German Academic Exchange Service, Hertie Foundation, Interdisciplinary Center for Clinical Studies (IZKF) Muenster, German Foundation Neurology, and by Almirall, Amicus Therapeutics Germany, Biogen, Diamed, Fresenius Medical Care, Genzyme, Merck Serono, Novartis, ONO Pharma, Roche, and Teva. C. Kleinschnitz received honoraria for lecturing and consulting as well as financial research support from Ablynx, Almirall, Amgen, Bayer Vital, Bristol-Mayers Squibb, Biotronik, Boehringer Ingelheim, Biogen, CSL Behring, Daiichi-Sankyo, Desitin, Eisai, Ever Pharma, Sanofi Genzyme, Merck Serono, Mylan, Medday, Novartis, Pfizer, Roche, Siemens, Stago, and Teva. R. Pul received honoraria for lecturing and consulting from Alexion, Bayer Healthcare, Biogen, Bristol-Mayers Squibb, MedDay, Merck Serono, Mylan, Novartis, Roche, and Sanofi Genzyme. He received research fund from Merck Serono and Novartis. Go to Neurology.org/NN for full disclosures.

\section{Publication History}

Received by Neurology: Neuroimmunology \& Neuroinflammation December 7, 2020. Accepted in final form February 16, 2021.

Appendix Authors

\begin{tabular}{lll}
\hline Name & Location & Contribution \\
\hline $\begin{array}{l}\text { Leoni Rolfes, } \\
\text { MD }\end{array}$ & $\begin{array}{l}\text { University Hospital } \\
\text { Münster, Münster, } \\
\text { Germany }\end{array}$ & $\begin{array}{l}\text { Study concept and design; } \\
\text { acquisition and interpretation } \\
\text { of data; and drafted the } \\
\text { manuscript }\end{array}$ \\
\hline $\begin{array}{l}\text { Steffen } \\
\text { Pfeuffer, MD }\end{array}$ & $\begin{array}{l}\text { University Hospital } \\
\text { Münster, Münster, } \\
\text { Germany }\end{array}$ & $\begin{array}{l}\text { Study concept and design and } \\
\text { acquisition and interpretation } \\
\text { of data }\end{array}$ \\
\hline
\end{tabular}

Appendix (continued)

\begin{tabular}{|c|c|c|}
\hline Name & Location & Contribution \\
\hline $\begin{array}{l}\text { Jana Hackert, } \\
\text { MD }\end{array}$ & $\begin{array}{l}\text { University Hospital } \\
\text { Essen, Essen, } \\
\text { Germany }\end{array}$ & Acquisition of data \\
\hline $\begin{array}{l}\text { Marc } \\
\text { Pawlitzki, MD }\end{array}$ & $\begin{array}{l}\text { University Hospital } \\
\text { Münster, Münster, } \\
\text { Germany }\end{array}$ & $\begin{array}{l}\text { Critical revision of the } \\
\text { manuscript for intellectual } \\
\text { content }\end{array}$ \\
\hline $\begin{array}{l}\text { Tobias Ruck, } \\
\text { MD }\end{array}$ & $\begin{array}{l}\text { University Hospital } \\
\text { Münster, Münster, } \\
\text { Germany }\end{array}$ & $\begin{array}{l}\text { Critical revision of the } \\
\text { manuscript for intellectual } \\
\text { content }\end{array}$ \\
\hline $\begin{array}{l}\text { Wiebke } \\
\text { Sondermann, } \\
\text { MD }\end{array}$ & $\begin{array}{l}\text { University Hospital } \\
\text { Essen, Essen, } \\
\text { Germany }\end{array}$ & $\begin{array}{l}\text { Critical revision of the } \\
\text { manuscript for intellectual } \\
\text { content }\end{array}$ \\
\hline $\begin{array}{l}\text { Melanie } \\
\text { Korsen, MD }\end{array}$ & $\begin{array}{l}\text { University Hospital } \\
\text { Essen, Essen, } \\
\text { Germany }\end{array}$ & $\begin{array}{l}\text { Critical revision of the } \\
\text { manuscript for intellectual } \\
\text { content }\end{array}$ \\
\hline $\begin{array}{l}\text { Heinz Wiendl, } \\
\text { MD }\end{array}$ & $\begin{array}{l}\text { University Hospital } \\
\text { Münster, Münster, } \\
\text { Germany }\end{array}$ & $\begin{array}{l}\text { Critical revision of the } \\
\text { manuscript for intellectual } \\
\text { content }\end{array}$ \\
\hline $\begin{array}{l}\text { Sven G. } \\
\text { Meuth, MD, } \\
\text { PhD }\end{array}$ & $\begin{array}{l}\text { University Hospital } \\
\text { Münster, Münster, } \\
\text { Germany }\end{array}$ & $\begin{array}{l}\text { Study concept and design and } \\
\text { critical revision of the } \\
\text { manuscript for intellectual } \\
\text { content }\end{array}$ \\
\hline $\begin{array}{l}\text { Christoph } \\
\text { Kleinschnitz, } \\
\text { MD }\end{array}$ & $\begin{array}{l}\text { University Hospital } \\
\text { Essen, Essen, } \\
\text { Germany }\end{array}$ & $\begin{array}{l}\text { Study concept and design and } \\
\text { critical revision of the } \\
\text { manuscript for intellectual } \\
\text { content }\end{array}$ \\
\hline Refik Pul, MD & $\begin{array}{l}\text { University Hospital } \\
\text { Essen, Essen, } \\
\text { Germany }\end{array}$ & $\begin{array}{l}\text { Study concept and design; } \\
\text { acquisition and interpretation } \\
\text { of data; and drafted the } \\
\text { manuscript }\end{array}$ \\
\hline
\end{tabular}

\section{References}

1. Chan JK, Traboulsee AL, Sayao AL. Case of alemtuzumab-related alopecia areata management in MS. Neurol Neuroimmunol Neuroinflamm 2019;6:e516. doi: 10.1212/NXI.0000000000000516.

2. Cook S, Leist T, Comi G, et al. Safety of cladribine tablets in the treatment of patients with multiple sclerosis: an integrated analysis. Mult Scler Relat Disord 2019;29. 157-167.

3. Mateo-Casas M, Reyes S, O’Toole EA, et al. Severe skin reactions associated with cladribine in people with multiple sclerosis. Mult Scler Relat Disord 2020;43:102140.

4. Giovannoni G, Soelberg Sorensen P, Cook S, et al. Safety and efficacy of cladribine tablets in patients with relapsing-remitting multiple sclerosis: results from the randomized extension trial of the CLARITY study. Mult Scler 2018;24:1594-1604.

5. Montalban X, Leist TP, Cohen BA, et al. Cladribine tablets added to IFN-beta in active relapsing MS: the ONWARD study. Neurol Neuroimmunol Neuroinflamm 2018;5:e477. doi: 10.1212/NXI.0000000000000477.

6. Leist TP, Comi G, Cree BA, et al. Effect of oral cladribine on time to conversion to clinically definite multiple sclerosis in patients with a first demyelinating event (ORACLE MS): a phase 3 randomised trial. Lancet Neurol 2014;13:257-267.

7. Giovannoni G, Comi G, Cook S, et al. A placebo-controlled trial of oral cladribine for relapsing multiple sclerosis. N Engl J Med 2010;362:416-426.

8. Ganzel C, Gatt ME, Maly A, Ben-Yehuda D, Goldschmidt N. High incidence of skin rash in patients with hairy cell leukemia treated with cladribine. Leuk Lymphoma 2012;53:1169-1173.

9. Cook S, Vermersch P, Comi G, et al. Safety and tolerability of cladribine tablets in multiple sclerosis: the CLARITY (CLAdRIbine Tablets treating multiple sclerosis orallY) study. Mult Scler 2011;17:578-593.

10. Gambichler T, Kulik MA, Skrygan M, Rooms I, Hoxtermann S. Cutaneous leukocytoclastic vasculitis: the role of lymphocytes and related immune markers. Postepy Dermatol Alergol 2017;34:299-305.

11. Ruck T, Pfeuffer S, Schulte-Mecklenbeck A, et al. Vitiligo after alemtuzumab treatment: secondary autoimmunity is not all about B cells. Neurology 2018;91: e2233-e2237. 


\title{
Neurology \\ Neuroimmunology \& Neuroinflammation
}

\author{
Skin Reactions in Patients With Multiple Sclerosis Receiving Cladribine Treatment \\ Leoni Rolfes, Steffen Pfeuffer, Jana Hackert, et al. \\ Neurol Neuroimmunol Neuroinflamm 2021;8; \\ DOI 10.1212/NXI.0000000000000990
}

This information is current as of April 9, 2021

Updated Information \&

Services

References

Subspecialty Collections

Permissions \& Licensing

Reprints including high resolution figures, can be found at:

http://nn.neurology.org/content/8/3/e990.full.html

This article cites 11 articles, 1 of which you can access for free at: http://nn.neurology.org/content/8/3/e990.full.html\#\#ref-list-1

This article, along with others on similar topics, appears in the following collection(s):

Autoimmune diseases

http://nn.neurology.org//cgi/collection/autoimmune_diseases

Class IV

http://nn.neurology.org//cgi/collection/class_iv

Multiple sclerosis

http://nn.neurology.org//cgi/collection/multiple_sclerosis

Information about reproducing this article in parts (figures,tables) or in its entirety can be found online at:

http://nn.neurology.org/misc/about.xhtml\#permissions

Information about ordering reprints can be found online:

http://nn.neurology.org/misc/addir.xhtml\#reprintsus

Neurol Neuroimmunol Neuroinflamm is an official journal of the American Academy of Neurology.

Published since April 2014, it is an open-access, online-only, continuous publication journal. Copyright

Copyright $\odot 2021$ The Author(s). Published by Wolters Kluwer Health, Inc. on behalf of the American

Academy of Neurology.. All rights reserved. Online ISSN: 2332-7812.

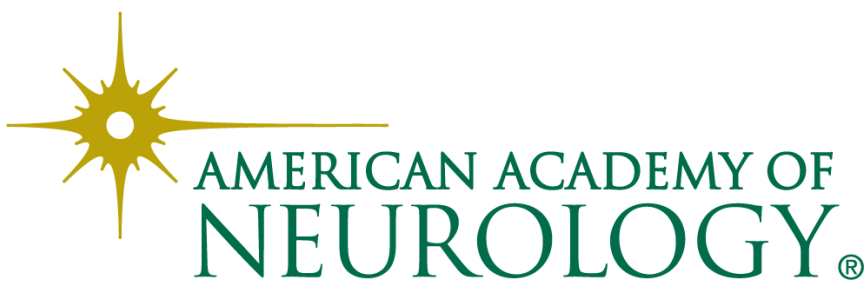

